\title{
Proposed Financial Statement Changes: Reactions To The FASB-IASB Discussion Paper
}

Don E. Giacomino, Marquette University, USA Michael D. Akers, Marquette University, USA

\begin{abstract}
The purpose of this study was to obtain the opinions of future users of the financial statements: current undergraduate and graduate students in accounting and academia. We found that the students show greater agreement with the proposed model than do the CPA's. In addition, we found that academia, as represented by the Financial Accounting Standards Committee of the American Accounting Association has a number of concerns regarding timing, user learning issues and impediments to learning, objectives and terminology and categorizing activities and assets and liabilities.
\end{abstract}

Keywords: IASB, FASB

\section{INTRODCUTION}

$\mathcal{Q}$ sers of financial statements have often stated their concerns about the inadequacy of the current formats of financial statements with respect to assisting users with their decisions. In 2004, in response to these concerns and as part of a memorandum of understanding regarding convergence of IAS and GAAP, the Financial Accounting Standards Board (FASB) and the International Accounting Standards Board (IASB) created a joint project on financial statement presentation. As MCClain and McLelland (2008) summarize:

This brought IAS 1 largely in line with FASB Statement no. 130, Reporting Comprehensive Income. FASB decided not to issue an exposure draft on its Phase a conclusions, but rather to issue a combined exposure draft for Phases $A$ and $B$.

FASB, however, did issue a set of tentative conclusions. Most significantly, a complete set of financial statements for a reporting period should include a statement of financial position, a statement of comprehensive income, a statement of changes in equity and a statement of cash flows. In addition, each financial statement should be shown with equal prominence, and a minimum of two years comparative information is required.

In contrast to IAS 1 (revised 2007), FASB would require a single statement of earnings and comprehensive income and require a subtotal for net income. IAS 1 (revised 2007) allows the presentation of non-owner changes in assets and liabilities to be presented in a single statement of comprehensive income or in two statements - a statement of profit or loss and a second statement starting with profit or loss and presenting components of other comprehensive income.

FASB also tentatively decided to allow (but provides no guidance for) voluntary presentation of financial information beyond the required two-year minimum for annual reports and to require the presentation of basic and diluted earnings per share on the statement of earnings and comprehensive income as the only per-share measure. FASB decided to continue to allow (but not require) the disclosure of basic and diluted comprehensive income per share in the notes and to require the disclosure of the weighted average number of shares used as the denominator in the calculation of per-share ratios in the notes. 


\section{The Discussion Paper and Board Meetings}

On June 30, 2008, the Boards issued their joint Discussion Paper, Preliminary View on Financial Statement Presentation. In the Discussion Paper, the boards propose a new model (format) for presenting financial statements. Their intention is to improve the usefulness of financial statements for decisions by users of the statements. Under the proposals, similar categories (Exhibit 2) of activities along the lines of the activities in the current Statement of Cash Flows will be used to format the three financial statements: Statement of Financial Position (Exhibit2), Statement of Comprehensive Income (Exhibit 3), and Statement of Cash Flows (Exhibit 4). Those categories are Business, Financing, Income Taxes, Discontinued Operations and Equity (Other Comprehensive Income for the Statement of Income). This represents a major departure from the current formats for each of the statements. In addition, their Discussion Paper proposes a Reconciliation Statement that reconciles cash flows to comprehensive income (Exhibit 5). The boards solicited written comments in response to the proposed financial statement presentation. April 14, 2009 was the deadline for those comments.

During the comment period, the boards field-tested the proposals to: (1) determine whether the proposed presentation model improves usefulness of the information to users in making their decisions as capital providers and (2) understand the costs of implementation and identify unintended consequences in applying the model. In their July 14, 2009 paper, the technical staffs of the FAF and IASCF discuss the purpose and background for the field test and the results of the survey.

\section{Purpose of this Article}

The purpose of this article is to summarize the financial statement format proposals from the joint boards (FASB and IASB) in their Discussion Paper and to examine reactions by CPAs, accounting and finance students, who are current and will be future users of financial statements) and academics. The first section of the paper summarizes the proposals for the three financial statements, Statement of Financial Position, Statement of Comprehensive Income, Statement of Cash Flows and the proposed Reconciliation of Cash Flows to Comprehensive Income. In the second section we present the findings of the FAF and IASCCF field testing of the proposed statements. In sections three and four respectively, we examine the reactions of CPAs from a study conducted by Shough (2009) with the responses from accounting and finance students that we surveyed. Comments and observations from the American Accounting Association Association's Financial Accounting Standards Committee are examined in section five while the final section provides a summary and our concluding comments.

\section{PROPOSED FORMAT OF THE FINANCIAL STATEMENTS}

\section{The Statement of Financial Position}

The financial statement most impacted by the Discussion Paper's proposals is the Statement of Financial Position. Current reporting for the Statement of Financial Position (Balance Sheet) calls for classifying/grouping items as assets, liabilities. However, the proposed format (Exhibit 3) for the Statement of Financial Position calls for grouping items by major business activities; operating, investing and financing. Firms would disclose assets and liabilities in the business and financing sections. Management would classify assets and liabilities into the sections (business and financing) and categories in the Statement of Financial Position based on how management thinks the asset or liability is used. Management would also determine the classification in the Statement of Comprehensive Income and the Statement of Cash Flows. Operating assets and liabilities are those that management sees as related to the central purpose of the entity and the investing assets and liabilities are those that management considers to be unrelated to the central purpose of the entity.

In addition, the Discussion Paper proposes:

- $\quad$ separating business activities from financing activities,

- $\quad$ showing information about financing of business activities according to source,

- $\quad$ including non-owner sources of financing in the financing section, 
- $\quad$ disclosing owner sources of financing in the equity section, and

- $\quad$ separating information about discontinued operations from continuing business and financing activities.

The Boards (FASB and IASB) also propose the elimination of cash equivalents. These securities would not be included as part of cash. Instead, they would be disclosed a part of short-term investments.

Management would disaggregate assets and liabilities according to their measurement bases and they would present them on separate line items in the Statement of Financial Position. One example would be separating securities measured at cost from securities measured at fair value.

\section{The Statement of Comprehensive Income}

Perhaps, the most significant change for reporting income is the proposed Statement of Comprehensive Income (Exhibit 4). This single statement separates business from financing activities and within business activities separates operating activities from investing activities. Discontinued operations are disclosed, but extraordinary transactions would no longer be disclosed. Neither comprehensive income nor other comprehensive income would be disclosed in a statement of changes in stockholder's equity.

\section{The Statement of Cash Flows}

The proposed Statement of Cash Flows (Exhibit 5) calls for separate disclosure of business activities, financing activities, income taxes, discontinued operations and equity. Of the two proposed major changes in the Statement of Cash Flows, mandated use of the direct method for computing is the most significant. Current cash flow reporting allows either the direct or indirect method; however, when the direct method is used, a firm must reconcile net income to cash flow from operating activities. In other words, by default, the indirect method is required. The Discussion Paper's proposed format would require a schedule in the notes that reconciles cash flows to comprehensive income - in other words, the indirect method. Thus, under the proposed format, both direct and indirect would be required. Another change, previously mentioned above, is the elimination of cash equivalents.

\section{The Reconciliation Schedule}

The proposed Reconciliation of the Statement of Cash Flows to the Statement of Comprehensive Income (Exhibit 6) is similar to the current indirect method of computing and presenting cash flows from operating activities. However, whereas the current format does a vertical reconciliation of net income, the proposed reconciliation is for a horizontal reconciliation of cash flows (under the direct method) to comprehensive income and other comprehensive income.

\section{Application}

All entities except not-for-profit and nonpublic entities would be required to comply with the proposed new financial statement presentations, if passed. According to the Discussion Paper, the FASB has not considered whether or not these requirements should apply to not-for-profit nonpublic entities.

\section{Field Testing}

The field testing (FAF and IASCF, July 2009) has three parts: (1) Preparer information: recast financial statements, preparer responses to post-completion survey, and cost estimates to implement the proposed presentation model. (2) Quantitative information that will provide a description of the additions, changes, and movements of line items between the non-recast and recast financial statements. (3) Analyst information: responses to a survey about their review of specific recast and non-recast financial statements. Of the 31 companies that were asked to submit recast financial statements for any two consecutive years under the proposed model, 29 submitted them and two withheld their statements (Regulation F-D concerns). Companies from seventeen industries and five countries participated. Following are selected findings from that survey: 
- $\quad$ Survey respondents thought the financing section and the investing category were not properly defined. However, most (60\%) said they encountered few issues in applying the definitions.

- Nearly $40 \%$ of the respondents encountered difficulties in classifying income, expenses, gains, losses or cash flows into the defined sections and categories.

- When classifying shared assets or liabilities used by activities in multiple sections or categories, $43 \%$ assigned them to the predominant use, $18 \%$ allocated them and $36 \%$ said they didn't have this type of shared assets or liabilities.

- Of the 27 responses on segment disclosure, 15 said that the management approach to classification supported and complemented their segment disclosures. Nine companies changed their segment disclosures.

- For the statement of financial position, there was not significant change in whether assets and liabilities were classified in short-term and long-term categories or presented in order of liquidity.

- $\quad$ Regarding disaggregation, only $39 \%$ of the preparers thought that the disaggregation guidance was appropriately defined and 54\% thought that application of the disaggregation guidance resulted in too much disaggregation overall.

- The majority of preparers stated that application of the disaggregation guidance was a distraction in communicating results in three areas: comprehensive income (43\%), cash flows $(50 \%)$ and the reconciliation schedule $(50 \%)$.

- $\quad$ There were significant increases (average 50\%) in the number of line items on the proposed statements.

- $\quad$ Responses were positive on cohesiveness (67\% said appropriately defined) and liquidity and financial flexibility ( $82 \%$ said this column was most useful of the four).

- $\quad$ Regarding communicating results were not as positive. Only $46 \%$ thought the recast statements did a better job than the non-recast statements in communicating the results of core operations. Only $25 \%$ thought the recast statements did a better job.

- $\quad$ Participants (32\%) felt that the management approach was the most useful aspect of the proposed model and the least useful aspects were the direct method of cash flows (61\%) and the reconciliation schedule $(54 \%)$.

- $\quad$ None of the participants indicated that the proposed presentation model identified their company's liquidity and financial flexibility better than the non-recast statements.

- $\quad$ Alignment of items across the statements (cohesiveness) was viewed positively (61\%) for the statement of comprehensive income, but negatively or no effect $(50+\%)$ for the other statements.

In summary, the majority of companies that implemented the proposed model believe that the recast statements communicate their results the same or worse than the non-recast statements. In addition, the staff (IASB and FASB) believes that the benefit of by-nature information on the face of the statements is not readily evident. The staff also questions whether the increase in line items (on the proposed model) equates to an increase in usefulness of the information presented. Finally, the staff also questions the effectiveness of the proposed definitions of the sections and categories and the disaggregation guidance.

In July 2009, the Joint International Group (JIG) and the Financial Institutions Advisory Group (FIAG) met to discuss the Discussion Paper and the results of field testing and to provide feedback on possible alternatives. The boards are deliberating the issues raised by respondents to the discussion paper and they expect to prepare an exposure draft for release in the second quarter of 2010.

\section{Reaction from CPA's}

Recently, Stuart Shough (2009) conducted a survey of CPA's to determine their receptiveness to the changes proposed in the Discussion Paper. Shough obtained the opinions of a sample of 605 CPA's in response to 19 questions (Table 2) about specific proposals for changes in the aggregations and categories of activities. Based on the answers from the CPA's who responded to his study, Shough (p. 107) concluded: 
The survey clearly shows that the CPA's do not think the objectives of the proposed financial statement presentation would improve the usefulness of the information provided in an entity's financial statements and help users make better decisions.

We show the results for the Shough survey in Table 1 and discuss those results in the next section that describes our study.

\section{Reactions from Students}

The IASB and FASB joint efforts have focused on the potential and cost of implementation of the proposed model for financial statement presentation. We see from the results of the recent implementation (by 31 companies) of the proposed model, that preparer's have many concerns about the decision usefulness of the proposals in the Discussion Paper.

Shough obtained the opinions of CPA's regarding the decision-usefulness of the proposed financial statement presentations in the Discussion Paper. These results should be considered seriously by the FASB and IASB as they continue to move toward the possibility of new requirements for presenting financial statements. Some CPA's do serve as users of the financial statements - in the context of auditing, corporate management, corporate financial reporting and consulting. However, the FASB Conceptual Framework Project has stated the main objective of financial reporting is to assist investors and creditors with their understanding of the amount, timing and uncertainty of an entity's future cash flows. Therefore, the purpose of our study is to determine the opinions of those users. In addition, we survey current accounting students (undergraduate-seniors and graduateMasters students) and undergraduate (juniors and seniors) finance students in an Applied Investment Management program. In conjunction with the findings from Shough's study, this additional input will give us a clearer picture of the acceptability of the proposals in the Discussion Paper. Also, this study will provide feedback not only on the proposed broad aggregations and categories, but also, on specific changes that are proposed.

Neither the implementation study nor Shough's study involves the main users (and main target audience of the FASB and IASB) of the financial statements --equity investors and creditors. Therefore, we conducted a study designed to obtain the opinions of equity and credit analysts. In order to compare out results with those from Shough's study, we used the same survey instrument. We also wanted to obtain the opinion of some future preparers, auditors and users of corporate financial statements. Therefore, we distributed the survey to accounting majors (seniors and graduate students) and applied investment management majors (juniors and seniors). Table 1 provides the results of surveys of the students and the large sample of CPA's (Shough's 2010 survey).

We distributed the survey instrument to 121 students at a private, Midwestern university. Respondents were undergraduate seniors and graduate-masters students majoring in accounting and juniors and seniors majoring in the Applied Investment Management program. Most of those students will be practicing as either preparers or users of financial statements. Many of them will be practicing as either equity analysts or credit analysts. Therefore, we believe that it is useful to obtain their reactions to the proposals in the Discussion Paper. Table 1 provides the results by question. Generally, the students were in agreement with the proposed financial statement presentation, as summarized below:

- $\quad$ Students felt that the proposed formatting (in Exhibit 2) improves usefulness (74\% agree) and the grouping of data by major activities (operating, investing and financing) is more decision useful than current formats.

- They also, favor that equity should be included as a section separate from financing (64\%). Regarding the disclosure of discontinued operations, students believe separate disclosure is decision useful (93\%). Only $28 \%$ favor breaking down discontinued operations into the relevant categories (operating, financing and investing).

- However, the students do not agree with the management approach to classifying assets and liabilities, $68 \%$ believe the approach does not provide the most useful information and $69 \%$ feel the potential for reduced comparability resulting from the management approach outweighs the benefits.

- Most $(57 \%)$ of the respondents agrees with separation of business and financing activities will make it easier to calculate some key financial ratios. 
- A majority (57\%) of the respondents believes that the business section and the operating and investing categories are defined appropriately.

- $\quad$ Regarding the financing section, respondents agree that the financing section and financing assets and liabilities are defined appropriately $(74 \%)$ and that the financing section should be restricted to financial liabilities as defined in IFRS and U.S. GAAP as proposed.

- $\quad$ Students (53\%) support elimination of cash equivalents from the cash account and showing these securities in a manner similar to other short-term investments.

- $\quad$ There is high agreement $(75 \%)$ that assets and liabilities should be disaggregated according to their measurement bases.

- $\quad$ Students also show strong agreement (71\%) with showing comprehensive income and its components in a separate statement of comprehensive income.

- $\quad$ Students support requiring the direct method for reporting cash flows from operating activities (64\% - 69\%) and believe (75\%) the proposed reconciliation statement increases users' understanding of an entity's future cash flows.

- $\quad$ Finally, respondents want (58\%) the FASB to apply the proposed model to nonpublic entities.

When comparing students' responses to CPA's responses, we see that students were more in agreement with the proposals in the Discussion Paper than were the CPA's. On six of the questions [(\#1 (usefulness), 2 (grouping), 9 (ratio computation easier), 10 (acceptance of definitions-business, operating and investing), 11 (acceptance of definitions-financing and relevant categories), 20 (application to nonpublic companies)], students agree with the proposed changes, but CPA's disagree. On only two questions [(\#7 (management approach), 13 (elimination of cash equivalents)] do a higher percentage of CPA's agree with the proposals; and those differences are small.

\section{Reaction from Academia}

The Financial Accounting Standards Committee of the American Accounting Association (AAA FASC, 2010) responded to the Discussion Paper in a March 2010 article published in Accounting Horizons. While the committee concluded that the project has "great potential to improve the usefulness of financial statements" (p. 158) potential concerns were also identified. The following concerns were identified by the committee:

- $\quad$ Timing of the proposal-proposal implies a conceptual framework although the FASB is still developing a conceptual framework.

- $\quad$ The proposed format would make the use of XBRL and data tag-base reports more challenging.

- $\quad$ The disaggregation objective is too vague - a succinct and concrete explanation should be provided.

- $\quad$ Add a financial leverage objective as follows "Help users assess the extent to which an entity employs financial leverage," (p. 152)

- Use the caption operating rather than "business".

- $\quad$ Specifically state the classification of preferred equity as either financing or equity.

- $\quad$ Present discontinued operations in the relevant categories rather than a separate section.

- $\quad$ Consider a more prescriptive approach to classifying assets and liabilities as the management approach allows too much latitude which can have either a positive or negative impact on the financial statements.

- Categorizing capital lease liabilities as financing or operating will be problematic, particularly under a management approach.

- Classification of assets and liabilities for those entities with more than one reportable segment at the entity level will probably be more complex that at the reportable segment level.

- $\quad$ Classification of preferred stock as a financial liability eliminates any definitional conflicts and makes the allocation of taxes to sections easier. differences:

Comparing the CPA and student reactions with the AAA FASC conclusions we see the following key 
- $\quad$ AAA FASC feels discontinued operations should be shown in the relevant categories while the CPAs and students believe a separate section should be used.

- While the survey questions ( 3 and 4) in Table 2 didn't identify the type of equity, both the CPAs and students were moderately supportive (64\%) of separating equity from financing and the students didn't support the inclusion of equity in financing. AAA FASC believes that preferred equity should be classified as a financial liability.

- The AAA FASC and CPAs don't support the use of "business" while there is only moderate support (57\%) from the students.

It is interesting to note that all groups agree that the management approach doesn't provide a more useful view of the entity.

\section{Summary and Conclusions}

Two years ago, the FASB and IASB prepared a joint discussion paper that proposes major changes to the form and content of financial statements. While awaiting comments on the Discussion Paper, in an effort to estimate costs and potential problems related to implementation, these groups had 31 companies attempt to implement the proposals. The implementation process has provided the FASB and IASB with useful information for considering revisions to the proposals. In addition, Professor Shough has surveyed 605 CPA's to get their feedback on the proposals. Shough found that many of the CPA's show concerns about the usefulness of the proposed model. Whereas, implementation has been tested and the feedback from CPA's (most of whom would be preparers and auditors), the feedback from users of the statements has not been obtained.

The purpose of this study was to obtain the opinions of future users of the financial statements: current undergraduate and graduate students in accounting and academia. We found that the students show greater agreement with the proposed model than do the CPA's. In addition, we found that academia, as represented by the Financial Accounting Standards Committee of the American Accounting Association has a number of concerns regarding timing, user learning issues and impediments to learning, objectives and terminology and categorizing activities and assets and liabilities.

Apparently, the implementation project yielded some major concerns about the proposed reconciliation schedule. After obtaining feedback from the implementation study, both boards (FASB and IASB) have tentatively decided to replace the proposed reconciliation schedule with a requirement to analyze the changes in balances of significant asset and liability line items (Lamoreaux 2010). The boards plan to issue an exposure draft in the second quarter of 2010 and a final standard a year later in the second quarter of 2011.

\section{AUTHOR INFORMATION}

Dr. Don E. Giacomino, CPA is Professor of Accounting and the Donald and Beverly Flynn Chair Holder at Marquette University. He earned a DBA from the University of Kentucky and the MBA from the University of Montana. Giacomino has published a Management Accounting text and over 50 refereed articles in academic and professional journals, including Advances in Accounting, Journal of College Teaching and Learning, Journal of Accountancy, the CPA Journal, Issues in Accounting Education, International Business and Economics Research Journal and Journal of Managerial Issues. He serves on the Board and Executive Committee of the Wisconsin Institute of CPAs.

Dr. Michael D. Akers, CPA, CIA, CMA, CFE, CBM is the Charles T. Horngren Professor of Accounting and Chair, Department of Accounting. He earned his doctoral degree at the University of Mississippi and his MBA at the University of Louisville. In addition to serving on the editorial advisory board of two journals, he has authored more than 50 articles in academic and professional journals. He currently serves on the Audit Committee and Board of Directors of two publicly traded companies. 


\section{REFERENCES}

1. American Accounting Association, 2010, "Response to the Financial Accounting Standards Board's and the International Accounting Standards Board's Joint Discussion Paper Entitled Preliminary Views on Financial Statement Presentation", Accounting Horizons, Vol. No. 1, March 2010, pp. 149-158.

2. FAF and IASCF technical staff. 2009. "Financial Statement Presentation-Filed test summary: preparer survey responses" http://www.iasb.org/NR/rdonlyres/CE06A32B-8147-4041-A249D298824AD26C/0/FSP0907b17Dobs.pdf

3. Lamoreaux, Matthew G. 2010. "Countdown to Convergence", Journal of Accountancy, March 10, 2010, pp. 24-29.

4. McClain, Guy and Andrew McLelland, "Shaking Up Financial Statement Presentation", Journal of Accountancy, November 2008.

5. Shough, Stewart, "What the CPA's Think about the Proposed Financial Statement Presentation”, Journal of Business and Economic Research, Volume 7, Number 11, November 2000, pp. 103-112.

Table 1

Responses to Discussion Paper Proposals

Question

1. Would proposed format improve decision usefulness?*

2. Grouping data by activities is more useful?

3. Separate equity from financing?

4. Include equity in financing?

5. Separate section for discontinued operations?

6. Disclose discontinued operations in relevant categories?

7. Management approach provides more useful view of entity?

8. Reduced comparability (of management approach) outweighs benefits?

9. Separating business and financing makes ratio computation easier?

10. Accept definitions: business section and operating and investing categories?

11. Accept definitions: financing section and relevant categories?

12. Restrict financing section to financial liabilities per IFRS \& GAAP?

13. Eliminate cash equivalents from cash and show as short-term investments?

14. Disaggregate assets and liabilities measured on different bases?

15. Prepare single statement of comprehensive income?

16. Direct method more useful for presenting cash flows from operations?

17. Direct method more consistent with cohesiveness and disaggregation?

18. Include current indirect method information in the proposed reconciliation?

19. Reconciliation statement increases understanding of future cash flows?

20. Should FASB apply the proposed model to nonpublic entities?

*The bold print indicates questions on which the student's agree with the proposals, but CPA's disagree.

** Questions 3 and 4 were part of one question for Shough's survey of CPA's. 
Table 2

Survey Regarding FASB-IASB Discussion Paper

Q\# Question

Would the objectives of financial statement presentation proposed in Exhibit 1 improve the usefulness of the information provided in an entity's

financial statements by helping users make better decisions in their capacity as capital providers?

2 Would the objectives of financial statement presentation proposed (Balance Sheet) would group data by major activities (operating, investing, and financing) not by assets, liabilities and equity as at present. Would the separation of business activities from financing activities provide information that is more decision useful than that provided in the financial statement formats used today?

The Boards concluded that information about the financing of business activities should be shown according to the source. The financing section would include nonowner sources of financing and the equity section would display information form owner sources.

3 Should equity be presented as a section separate from the financing section?

4 Should equity be included as a category in the financing section?

In the Statement of Financial Position, information about discontinued operation would be shown separately from its continuing business and financing activities.

In the proposed presentation model, an entity would present its discontinued operations in a separate section.

5 Does this presentation provide decision useful information?

6 Instead of presenting this information in a separate section, should an entity present information about its discontinued operations in the relevant categories (operating, investing, financing assets and financing liabilities?

Management would classify its assets and liabilities into the sections and categories in the statement of financial position based on how management thinks the asset or liability is used within the entity. This classification by management would determine the classification in the statements of comprehensive income and cash flows. The proposed presentation model relies on a management approach to

relies on a management approach to classification of assets and liabilities and the related changes in those items In the sections and categories in order to reflect the way an item is used within the entity or its reportable segment.

7 Would a management approach provide the most useful view of an entity to users of its financial statements?

8 Would the potential for reduced comparability of financial statements resulting from a management approach to classification outweigh the benefits of that approach?

The paper (Boards' proposal) proposes that both assets and liabilities should be presented in the business section and in the financing section of the statement of financial position.

9 Would this change in presentation coupled with the separation of business and financing activities in the statements of comprehensive income and cash flows make it easier for users to calculate some key financial ratios for an entity's business activities or its financing activities?

The Discussion Paper states that the business section should include assets and liabilities that management views as part of its continuing business activities of producing goods or providing services with customers, suppliers and employees. The operating category should

include assets and liabilities that management views as related to the central purpose for which the entity is in business and the investing

category should include assets and liabilities that management views as unrelated to the central purpose for which the entity is in business.

10 Are the business section and the operating and investing categories within that section defined appropriately? 
The Boards required disaggregation of assets and liabilities according their measurement bases and present them on separate lines in the statement of financial position. For example, securities measured at amortized cost and securities measured at fair value should be shown on separate lines.

14 An entity should present its similar assets and liabilities that are measured on different bases on separate lines in the statement of financial position Would this disaggregation provide information that is more useful than a presentation that permits line items to include similar assets and liabilities measured on different bases?

There is to be only a single Statement of Comprehensive Income (Exhibit 3) of which net income or loss would be a subtotal. Comprehensive income and other comprehensive income would no longer be allowed to be shown in the statement of changes in stockholder's equity.

15 Should an entity present comprehensive income and its components in a single statement of comprehensive income as proposed?

There are two major changes in the proposed format of the Statement of Cash Flows (Exhibit 4). Firstly, the elimination of cash equivalents and secondly, the entity would use the direct method to present its cash receipts and cash payments. The use of the indirect method would no longer be allowed for the operating activities section of the statement of cash flows.

16 The paper proposed that an entity should use the direct method of presenting cash flows in the statement of cash flows. Would the direct method provide information that is decision useful?

17 Is the direct method more consistent with the proposed cohesiveness and disaggregation objective than the indirect method?

18 Would the information currently provided using the indirect method to present operating cash flows be provided in the proposed reconciliation schedule?

A new Reconciliation Schedule (Exhibit 5) will be presented in the notes to the financial statements. This schedule reconciles cash flows to comprehensive income and disaggregates comprehensive income into four components: (a) cash received or paid other than in transaction with owners, (b) accruals other than remeasurement, (c) remeasurements that are recurring fair value changes or valuation adjustments, and (d) remeasurement that are not recurring fair value changes or valuation adjustments.

19 Would the proposed reconciliation schedule increase users' understanding of the amount, timing and uncertainty of an entity's future cash flows?

The proposed financial statements presentation would apply to all entities except for not-for-profit entities and nonpublic entities. The

Discussion Paper states that the FASB has not considered explicitly whether this model should apply to nonpublic entities.

20 Do you think the FASB should consider applying the proposed model to nonpublic entities? 
Exhibit 1

Working Format for Presenting Information in the Financial Statements

\begin{tabular}{|lll|}
\hline \multicolumn{1}{|c|}{ Statement of } & Statement of \\
\hline Statement of & Comprehensive Income & Cash Flows \\
\hline & & Business \\
\hline Business & Business & - Operating Cash Flows \\
\hline - Operating Assets \& Liabilities & - Operating Income \& Expense & - Investing Cash Flows \\
\hline - Investing Assets \& Liabilities & - Investing Income \& Expense & Financing \\
\hline & & - Financing Asset Cash Flows \\
\hline Financing & Financing & - Financing Liability Cash Flows \\
\hline - Financing Assets & - Financing Asset Income & Income Taxes \\
\hline - Financing Liabilities & - Financial Liability Expense & \\
\hline & & Discontinued Operations \\
\hline Income Taxes & Income Taxes (related to & \\
\hline & business and financing) & \\
\hline Discontinued Operations & Discontinued Operations, & Equity \\
\hline & Net of Tax & \\
\hline Equity & Other Comprehensive Income, & \\
\hline & Net of Tax & \\
\hline
\end{tabular}


Exhibit 2

Hutch Manufacturing Co. Statements of Financial Position

\begin{tabular}{|c|c|c|c|}
\hline & Net operating assets & 137,000 & 115,000 \\
\hline \multicolumn{4}{|c|}{ Investing assets and liabilities } \\
\hline \multicolumn{4}{|c|}{ Long term } \\
\hline \multicolumn{2}{|c|}{ Available-for-sale securities } & 2,000 & 3,000 \\
\hline & Investment in affiliate - equity method & $\underline{6,000}$ & $\underline{5,000}$ \\
\hline \multicolumn{2}{|c|}{ Total investing assets } & $\overline{8,000}$ & 8,000 \\
\hline & Net business assets & 145,000 & 123,000 \\
\hline \multicolumn{4}{|c|}{ FINANCING } \\
\hline \multicolumn{4}{|c|}{ Financing assets } \\
\hline \multicolumn{2}{|c|}{\begin{tabular}{|l|l|l} 
Short term & \\
\end{tabular}} & 92,000 & 94,000 \\
\hline Cash & & $\overline{92,000}$ & $\overline{94,000}$ \\
\hline & Total financing assets & & \\
\hline \multicolumn{4}{|c|}{ Financing liabilities } \\
\hline \multicolumn{4}{|c|}{\begin{tabular}{|l|l} 
Short term & \\
\end{tabular}} \\
\hline \multicolumn{2}{|c|}{ Dividends payable } & $(3,000)$ & $(3,000)$ \\
\hline \multicolumn{2}{|c|}{ Short-term debt and current portion of long-term } & $(14,000)$ & $(1,000)$ \\
\hline & Short-term financing liabilities & $\overline{(17,000)}$ & $(4,000)$ \\
\hline \multicolumn{4}{|l|}{ Long term } \\
\hline \multicolumn{2}{|c|}{$\begin{array}{l}\text { term } \\
\text { Long-term debt }\end{array}$} & $(71,000)$ & $(49,000)$ \\
\hline & Long-term financing liabilities & $(71,000)$ & $(49,000)$ \\
\hline & Net financing assets & 4,000 & 41,000 \\
\hline \multicolumn{4}{|c|}{ INCOME TAXES } \\
\hline \multicolumn{4}{|c|}{\begin{tabular}{|l|l} 
Short term & \\
\end{tabular}} \\
\hline \multicolumn{2}{|c|}{ Income taxes payable } & $(8,000)$ & $(12,000)$ \\
\hline Long term & & & \\
\hline Defer & red tax assets, net & $\underline{10,500}$ & $\underline{13,500}$ \\
\hline & Net income tax assets & $\overline{2,500}$ & $\overline{1,500}$ \\
\hline DISCONTI & INUED OPERATIONS & & \\
\hline Assets class & ified as held for sale & 20,000 & 22,000 \\
\hline Liabilities cla & assified as held for sale & $(8,000)$ & $(8,000)$ \\
\hline & Net assets held for sale & 12,000 & 14,000 \\
\hline EQUITY & & & \\
\hline Comm & non stock and additional paid in capital & $(47,000)$ & $(40,000)$ \\
\hline Treasi & ury stock & 142,000 & 97,000 \\
\hline Retain & hed earnings & $(250,750)$ & $(228,000)$ \\
\hline Accur & mulated other comprehensive income & $(7,750)$ & $(8,500)$ \\
\hline & Total equity & $\$ \quad(163,500)$ & $(179,500)$ \\
\hline & & & \\
\hline & & & \\
\hline & & & \\
\hline & & & \\
\hline & & & \\
\hline & & & \\
\hline & & & \\
\hline & & & \\
\hline & & & \\
\hline & & & \\
\hline & & & \\
\hline & & & \\
\hline & & & \\
\hline & & & \\
\hline & & & \\
\hline & & & \\
\hline & & & \\
\hline & & & \\
\hline & & & \\
\hline & & & \\
\hline & & & \\
\hline
\end{tabular}


Exhibit 3

Hutch Manufacturing Co. Consolidated Statements of Comprehensive Income

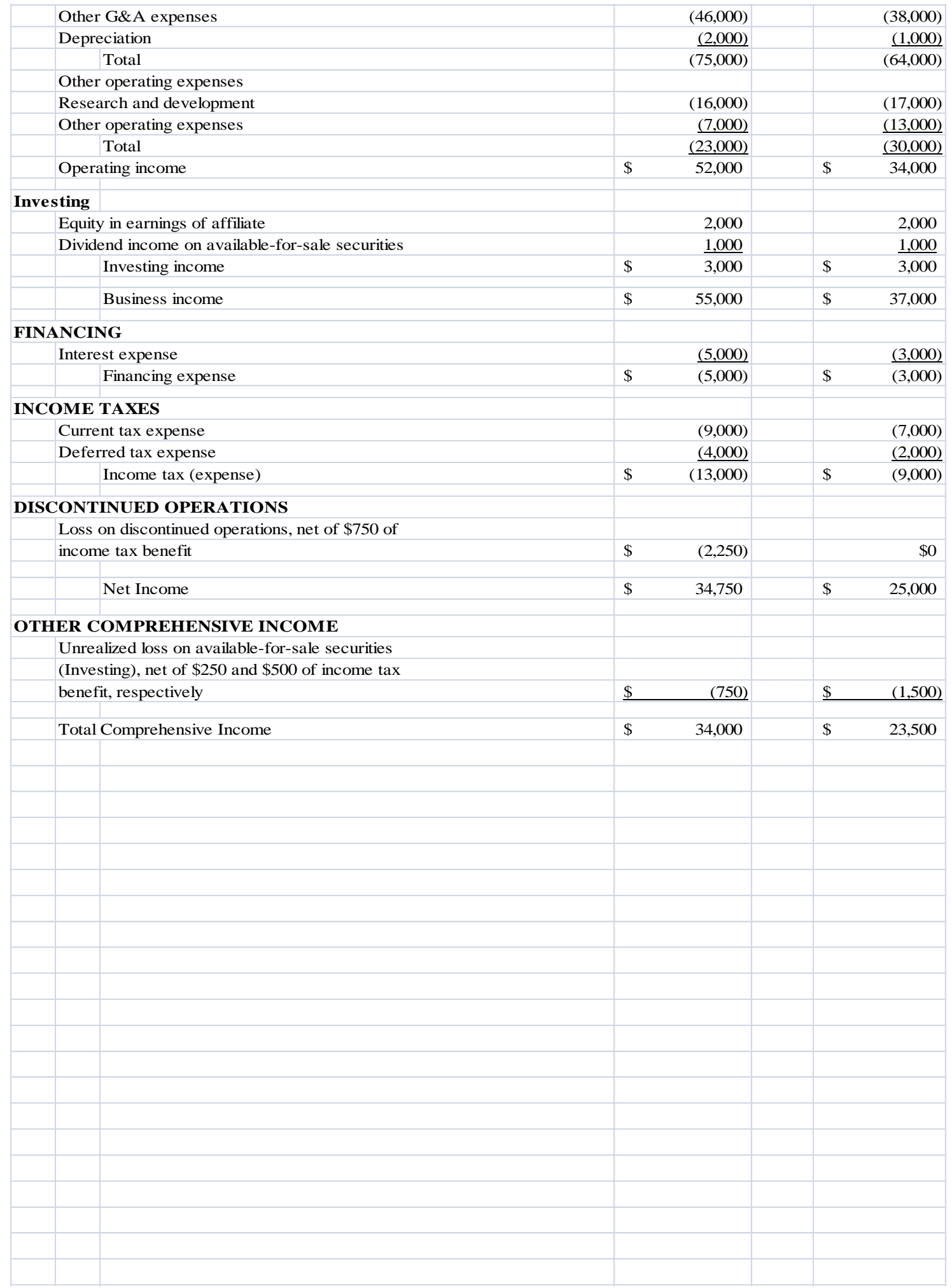


Exhibit 4

Hutch Manufacturing Co. Consolidated Statements of Cash Flow

Cash paid for other operating activities

Research and development

Capital expenditures

Other

Total

Net cash provided by operating activities

Investing

Dividends received

Dividends received

Net cash provided from investing activities

Net cash provided by business activities

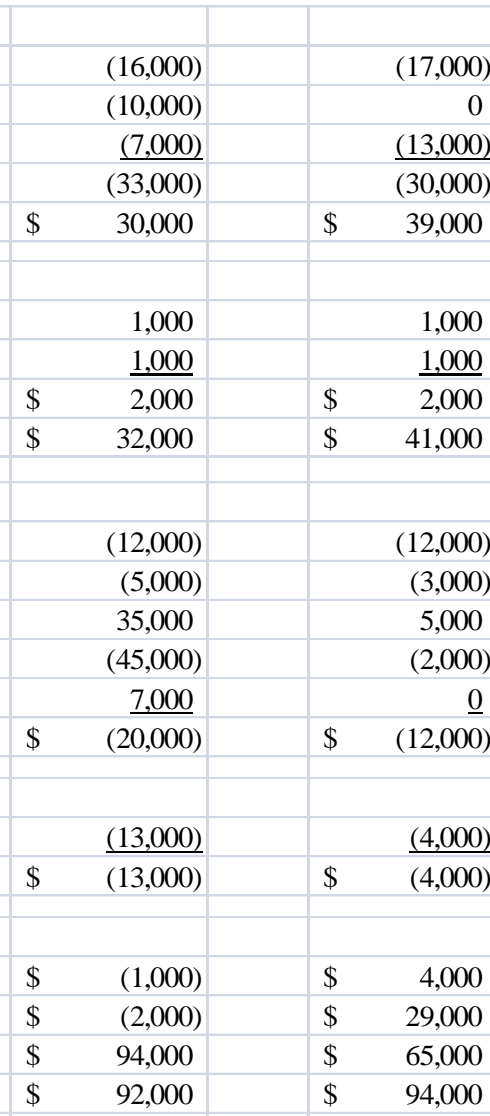

Financing

Dividends paid

Interest paid

Proceeds from debt

Purchases of treasury stock

Proceeds from common stock

Net cash used in financing activities

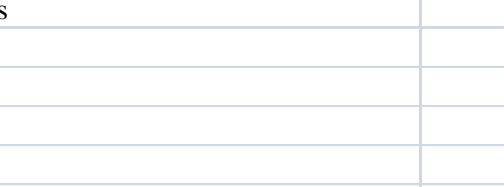

$(7,000)$

(30,000)

Income Taxes

Income taxes paid

(a)

Net cash used in income tax activities

Discontinued ope rations

Cash flows used in discontinued operations

Change in cash

Beginning cash

92,000

5,000

000)

Ending cash

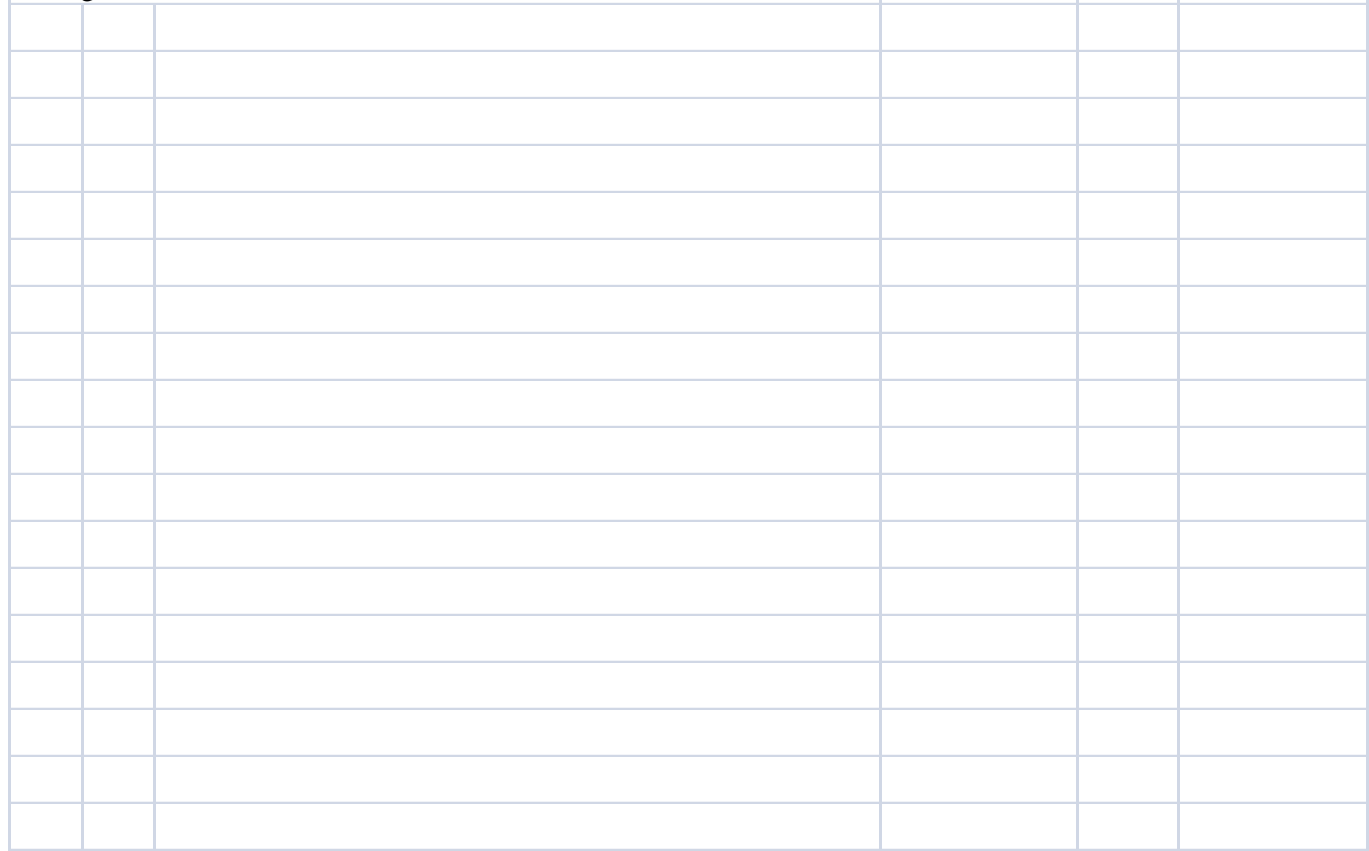


Exhibit 5

Hutch Manufacturing Co. Reconciliation of the Statement of Cash Flows to the Statement of Comprehensive Income

\begin{tabular}{|c|c|c|c|c|c|c|}
\hline & Cash Flows & $\begin{array}{l}\text { Accruals, } \\
\text { Allocations and } \\
\text { other changes }\end{array}$ & $\begin{array}{l}\text { Recurring } \\
\text { Fair Value } \\
\text { Changes }\end{array}$ & \begin{tabular}{|l|} 
Remeasurements Other \\
Than Recurring Fair Value \\
Changes
\end{tabular} & $\begin{array}{l}\text { Comprehensive } \\
\text { Income }(A+B+C+D)\end{array}$ & \\
\hline CASH FLOWS FROM BUSINESS & & & & & & BUSINESS \\
\hline Operating & & & & & & Operating \\
\hline Cash received from sales & 370,000 & 14,000 & & & 384,000 & Sales \\
\hline \multirow[t]{2}{*}{ Cash paid for goods sold } & & & & & & Cost of goods sold \\
\hline & & 6,000 & & & 6,000 & Change in inventory \\
\hline Inventory purchases & $(132,000)$ & $(3,000)$ & & & $(135,000)$ & Materials \\
\hline \multirow[t]{2}{*}{ Labor } & $(28,000)$ & & & & $(28,000)$ & Labor \\
\hline & & $(1,000)$ & & & $(1,000)$ & Overhead - Depreciation \\
\hline \multirow[t]{2}{*}{ Total } & $(160,000)$ & 2,000 & & & $(158,000)$ & Total \\
\hline & & & & & 226,000 & Gross profit on sales \\
\hline Cash paid for selling activities & & & & & & Selling expenses \\
\hline Compensation & $(5,000)$ & & & & $(5,000)$ & Compensation expense \\
\hline \multirow[t]{2}{*}{ Advertising } & $(38,000)$ & $(5,000)$ & & & $(43,000)$ & Advertising expense \\
\hline & & $(1,000)$ & & & $(1,000)$ & Bad debt expense \\
\hline Other selling & $(25,000)$ & $(2,000)$ & & & $(27,000)$ & Other selling expenses \\
\hline Total & $(68,000)$ & $(8,000)$ & & & $(76,000)$ & Total \\
\hline Cash paid for general and administration activities & & & & & & Gen \& Admin \\
\hline Compensation & $(15,000)$ & & & & $(15,000)$ & Compensation expense \\
\hline \multirow[t]{2}{*}{ Rent } & $(5,000)$ & & & & $(5,000)$ & Rent expense \\
\hline & & $(7,000)$ & & & $(7,000)$ & Amortization expense \\
\hline \multirow[t]{2}{*}{ Other general and administrative } & $(59,000)$ & 18,000 & & $(5,000)$ & $(46,000)$ & Other G\&A expenses and goodwill impairment \\
\hline & & $(2,000)$ & & & $(2,000)$ & Depreciation \\
\hline Total & $(79,000)$ & 9,000 & & $(5,000)$ & $(75,000)$ & Total \\
\hline Cash paid for other operating activities & & & & & & Other operating expenses \\
\hline Research and development & $(16,000)$ & & & & $(16,000)$ & Total \\
\hline Capital expenditures & $(10,000)$ & 10,000 & & & & \\
\hline Other & $(7,000)$ & & & & $(7,000)$ & Other operating expenses \\
\hline Total & $(33,000)$ & 10,000 & & & $(23,000)$ & Total \\
\hline Net cash provided by operating activities & 30,000 & 27,000 & & $(5,000)$ & 52,000 & Operating income \\
\hline Investing & & & & & & Investing \\
\hline Dividends received & 1,000 & 1,000 & & & 2,000 & Equity in earnings of affiliate \\
\hline Dividends received & 1,000 & & & & 1,000 & Dividend income on AFS securities \\
\hline Net cash provided from investing activities & 2,000 & 1,000 & & & 3,000 & Investing income \\
\hline Net cash provided by business activities & 32,000 & 28,000 & & & 55,000 & Business income \\
\hline Financing & & & & & & Financing \\
\hline Interest paid & $(5,000)$ & & & & $(5,000)$ & Interest expense \\
\hline \multirow[t]{2}{*}{ Proceeds from debt } & 35,000 & $(35,000)$ & & & & \\
\hline & & & & & $(5,000)$ & Financing expense \\
\hline Income Taxes & & & & & & Income Taxes \\
\hline \multirow[t]{2}{*}{ Income taxes paid } & $(13,000)$ & 4,000 & & & $(9,000)$ & Current tax expense \\
\hline & & $(4,000)$ & & & $(4,000)$ & Deferred tax expense \\
\hline Net cash used in income tax activities & $(13,000)$ & & & & $(13,000)$ & Income tax expense \\
\hline Discountinued Operations & & & & & & Discountinued Operations \\
\hline \multirow[t]{3}{*}{ Cash flows used in discountinued operations } & $(1,000)$ & & & $(1,250)$ & $(2,250)$ & Loss on discountinued operations \\
\hline & & & & & & Other Comprehensive Income \\
\hline & & & (750) & & $(750)$ & Unrealized loss on AFS securities \\
\hline Net cash provided by activities with non-equity holders & 48,000 & $(7,000)$ & (750) & $(6,250)$ & 34,000 & Total Comprehensive Income \\
\hline & & & & & & \\
\hline & & & & & & \\
\hline & & & & & & \\
\hline
\end{tabular}


NOTES 